\title{
Linguistic sign and reading as text creating activity
}

\author{
Olga Karamalak - Svetlana Pesina
}

\section{DOI: 10.18355/XL.2017.10.01.01}

\begin{abstract}
The article is devoted to the theoretical understanding of linguistic sign functioning in the process of semiosis within the framework of cognitive paradigm. It discusses the process of sign formation from the anthropological perspective, reviews the traditional treatment of a linguistic sign theory, postulating the continuity of the signified and the signifier, presents a critic argument concerning "information transfer". Moreover, it expands F. de Saussure's understanding of a linguistic sign and reconsiders the psychological part of a linguistic sign into a mnemonic structure, explaining semiosis differently.

The current paper criticizes the viewpoint according to which a reader is considered as a passive recipient. On the opposite it suggests that a reader is an active member of the interpretation process who generates the meaning of the linguistic sign in a personal and creative way.

Reading is realized as a complex psychological process, connected with speech and different kinds of perception (acoustic, visual, spatial, cognitive, and so on.). This implies an action from the part of the reader. The process of reading integrates perception, attention, memory, and thinking. Obviously, reading is a hyper active phenomenon.
\end{abstract}

Key words: linguistic sign, mnemonic structure, affordance, text, reading, semiosis, active reader

\section{Introduction}

In linguistics, there still exist some old-fashioned, stagnant views on a linguistic sign and a text as an estranged thing from the human brain and a written down "still and stiff" code that can be decoded while reading with the use of the same code. Many literature scientists speak about the internal life of the text and its synergetic being and consider a text as a self-developing and self-reorganizing system. Thus, they go deep into studying texts as a sort of containers full of meanings to be retrieved. Such traditional research lacks dynamism and diminishes the role of a human being in generating the meaning of the text. The development of cognitive science demands a new approach to a text.

The appeal to the human factor in language confirms a very important methodological change outlined in cognitive linguistics, the shift from immanent linguistics with its concentration on the language within itself and for itself to the anthropological linguistics implicating the consideration of language in close connection with a human being.

The nature of a linguistic sign is revealed in the dynamic process of semiosis, and the signified as well as the signifier appear to be unified but discrete entities. A tangible material form of a linguistic sign doesn't comprise a meaning but it affords to generate the meaning in this or that context. This understanding of a linguistic material form results from Gibson's ecological psychology (Gibson, 1977).

The objectives of the paper are to present speculations on a linguistic sign, a text and reading from a new modern cognitive, anthropological, distributed and ecological perspectives. 
The article methodology comprises Saussure's dual psychological understanding of a linguistic sign (Saussure, 1916/1922) added up with material linguistic form that is perceived and allows affordances in the interaction of an organism (a reader) and environment (a text) in ecological sense.

The scientific novelty of the study is determined by the fact that a linguistic sign is examined on cognitive perspective, the traditional notion of the "information transfer" in the process of communication is reconsidered (Harris, 1981; Love 2004; Kravchenko, 2001; 2003). The linguistic model of a communicative act on the sign level is formulated and the orienting character of a linguistic sign form is emphasized.

Reading as a part of a language activity is understood as distributed, socially shared, aspect of a human life because it comprises observers, physical environment (text, setting, writing devices), mental abilities (prior knowledge and experience, attitudes and motivation, script knowledge and beliefs about the world derived from repeated experiences with people, places, events, situations in day-today living), cultural aspect (customs, traditions, some stereotypes), and linguistic features (language structures, vocabulary, word meanings, spelling patterns, context, grammar, punctuation, etc.). Text reading is viewed as creation or realization of cultural artifacts and externalized sources, which afford us to get informed, extend and at the same time constrain our cultural environment.

\section{Linguistic sign on cognitive perspective}

The research of a linguistic sign nature in the classical and modern works of Russian and foreign linguists: Arkhipov (2001), Voloshinov (1929), Zalevskaya (2001), Kravchenko (2007), Kybryakova (1993), Morris (1938), Ogden (1923), Pesina (2005), Peirce (1958), Potebnya (1993), Richards (1923), Ferdinand de Saussure (1916/1922), Fortunatov (1956), Frege (1977) and others allows us to make a conclusion that a linguistic sign consists of physical entities (the form of the sign, which can be either acoustic or graphical and the referent - material things) and psychological which is also physical but not tangible (the mnemonic structure - the sound/written image and the concept, that consists of the common conceptual/notional meaning and the individual sense). In this paper, the research of the psychological constituent of a linguistic sign is based on the model of Ferdinand de Saussure (Saussure 1916/1922), who, as it is commonly known, considers a sign as bilateral psychological entity comprising a concept and a sound image.

Whereas the structure of F.de Saussure, according to his own statement, doesn't give a whole picture of a linguistic sign, we consider that this proposed part can be named as "mnemonic structure". The word "mnemonic" is derived from

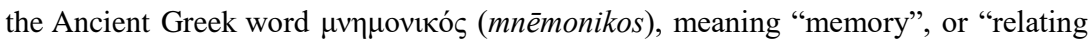
to memory" and is related to Mnemosyne ("remembrance"), the name of the goddess of memory in Greek mythology. Both of these words are derived from $\mu \nu \eta \mu \eta$ $(m n \bar{e} m \bar{e})$, "remembrance, memory". The psychological part of the linguistic sign is formed in our brain as a result of electro-chemical impulses, when a sound or written image matches the concept. The mnemonic structure of the linguistic sign can be represented by this diagram (Picture 1 ).

Pic. 1. Mnemonic structure of a linguistic sign

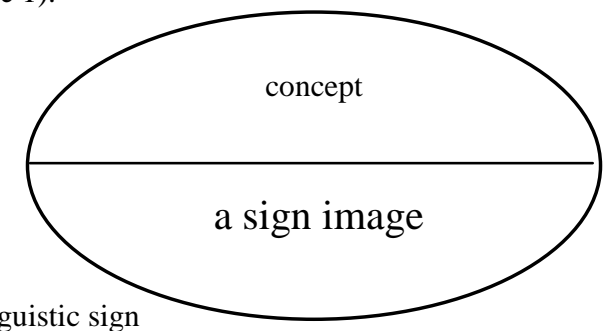

3

XLinguae Journal, Volume 10 Issue 1, January 2017, ISSN 1337-8384 
A concept as a substantial part of a language sign in the study (following the ideas of Damasio, Kravchenko, Maturana and others) is understood as the mental activity that takes place in the brain cortex (Damasio, 1995; Kravchenko, 2008; Maturana, 1978). The sound image can be renamed into «a sign image», because it might have the graphic form besides the acoustic one.

So our understanding of the linguistic sign functioning in the process of semiosis is represented graphically in Picture 2.

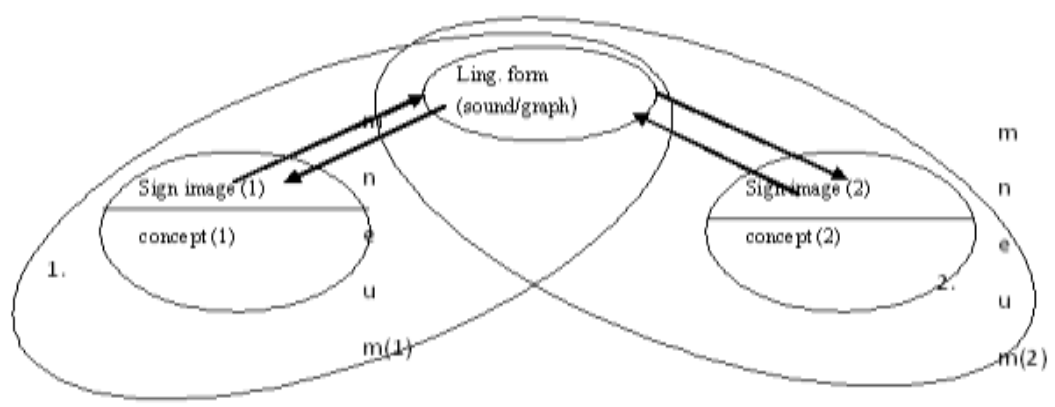

Pic. 2. The model of communication on the sign level

Two big ovals mean the two linguistic signs of the interlocutor (1) and the interlocutor (2). A linguistic sign represents a complex of mental (psychological) and tangible (material) entities which are both physical. The mental side of the language sign as a totality of a concept and sound/graphic image form of the sign represents the mnemonic structure. The physical entity of the language sign is a linguistic form of a sign (sound/ graphic(al) form of the sign).

The current paper criticizes the process of mechanical communication, according to which a reader is considered as a passive recipient. On the opposite, it suggests that a reader is an active member of interpretation who works to generate the meaning of the linguistic sign. It presents semiosis as a creative process.

Beginning communication, a speaker/writer forms some configuration of the meaning. i.e. the substantial part of signs. "The completion" of a linguistic sign takes place when the speaker "matches" the meaning to a sound or graphic(al) form. This is made only for yourself in other words the producer of a message controls his/her part of the communication and assures the output of the sign, corresponding to the initial intention (plan). There is no transmitted information in communication" (Maturana, Varela, 1987). Information is not transmitted from a sender to a receiver by a tube metaphor. Each person says what he says or hears what he hears according to his own structural determination; saying does not ensure listening" (Maturana, Varela, 1987). As for the listener or the reader, he/she receives not namely a linguistic sign, but only its form by way of the configurations of sounds or finger-prints on paper (material elements). Perceiving the sound/written form, the listener/reader activates the sound/written pattern of the sign's form and then the concept, which can be different from the speaker's concept. This concept consists of a common nucleus meaning and a personal sense dependent on the previous experience and background.

Thus, during semiosis, only the material (tangible for perception) form of the linguistic sign is one and the same for both, the speaker/writer and the listener/reader, whereas the mental (mnemonic) part of the sign (the meaning) is 
generated by the listener/reader and can be different from that of the speaker's or writer's.

It is wrong to assume that the linguistic sign (1) is equal to the linguistic sign (2), this equality is relative because the mnemonic structures can be slightly different as the listener/reader activates his/her own concept (sense and value) which may not correspond totally to that of the speaker or writer's. Engaging in verbal discourse, people try to "find" appropriate words which can "convey" their "ideas" though one can never be sure that the other communicator will interpret them the way he/she wants. Verbal signals do not "represent" meaning, they serve as coordinating signals (Kravchenko, 2007) constitutive of communication as joint action where nonverbal coordinating signals such as hand-movements, facial expression, eye-contact, touch, etc. play a great part. At the same time, they can be all ripe areas for interpretation. The same happen to reading, written signs do not represent meanings.

Maturana's mechanism of interlocutors' mutual understanding, when mnem (1) matches mnem (2) is named "consensual". By consensual domain of interaction we mean, in Maturanian terms (Maturana 1978), structural and mostly social coupling that is structural and social changes in the interacting systems which result in the continuous selection in them of congruent dynamics of state. Consensual domain is the juncture between two observers. A consensual domain is defined as "... a domain of interlocked (intercalated and mutually triggering) sequences of states, established and determined through ontogenic interactions between structurally plastic statedetermined systems." (Maturana, 1970). The notion consensual is something like mutual and cooperational. Mamardashvili suggests another term "congenial" (Mamardashvili, 1989). Strictly speaking, there is no thought transference. Such concepts as "information transfer", "channel of communication" have a figurative meaning, they are conduit metaphors. The listener himself/herself creates the information while communicating with the interlocutor. The existence of active and passive parts of the communication act turns out to be a myth as both communicators are active during the process of interaction.

A linguistic sign exists in the human consciousness as the unity of a form and content. While perceiving a word (an external stimulus) the mnemonic structure is activated in human mind. It comprises acoustic/graphic image of a sign form and a concept, some cognitive informational state of consciousness reflecting common, social and personal experience of an individual. The nature of a linguistic sign is revealed in the dynamic process of semiosis, and the signified as well as the signifier appear to be unified but discrete entities.

In the process of verbal communication or reading both interlocutors are active as well as a reader, the «information transfer» is a conduit metaphor. A person perceiving the linguistic form makes the sign content actual, people do not get linguistic signs ready-made in a passive way, because the sign form does not comprise as a capsule the unity of the signified and the signifier. A listener or a reader generates his or her own thought, which is sometimes not similar to the one the speaker or writer has meant. The congeniality of speaker and listener's or writer and reader's thoughts takes place because of the general character or peculiar concept nucleus (notional essence) which can be explained by similar social, cultural, language environment.

Therefore, it is wrong to consider that a linguistic form comprises a concept like in a capsule. The form of the sign has an orienteering function for a person (Kravchenko, 2001; 2003, Maturana, 1978). Neither oral speech, nor writing are techniques of thought transmission, they are just the techniques of stimulus transmission, which can only provoke thoughts.

A linguistic sign occurs "here-and-now" like a flash for a short period of time when a reader interacts with the text which is meaningful, sign images blend 
with or trigger concepts. A text can be read and interpreted only when a human being finds it meaningful and valuable. A text as well as a word outside the focus of a person's active mind is not a linguistic sign. The meaning of a word cannot be taken out as something passively holds. It is formed by a person depending on the context and the general and personal worldview. Perceiving the form of a language sign, i.e. a word, a person activates the sign content or a concept while completing the language sign (as the two-sided entity).

\section{Text as affordances}

This article views text from the distributed perspective. Texts link people with each other, being external resources and cultural traditions. This idea comes from viewing language as ecological and dialogical (Cowley, 2011). By ecological it means that organism and environment are inseparable and language is neither localized within a person nor a property of the environment. Language, action and perception can all describe the same events. To read, for example, is to perceive and, necessarily, to actively construe what one sees.

We do not treat texts as 'language' fixed by a code, a set of definite structures to be analyzed - but, rather, what acts of writing/reading and their consequences mean for those involved.

A text as a piece of writing is about "other orientation" rather than information transfer. Learning to read and write affects cognitive power and plays a very important role in human evolution and mind development. The earlier the child is exposed to written texts the smarter the person will be.

By a "text" we understand any instances of language, in any medium, that makes sense to someone who knows the language (Halliday, 2000). Following Gibson's ecological approach to perception, the body of the text is not sense-making symbols by themselves, but the affordances or opportunities for behavior which are meaningful to an observer. "The affordances of the environment are what it offers the animal, what it provides or furnishes, either for good or ill" (Gibson, 1979).

There appears a question if the affordances are properties of the environment or the organism. Gibson himself answers this question the following way "An affordance is neither an objective property nor a subjective property; or it is both if you like. An affordance cuts across the dichotomy of subjective-objective and helps us to understand its inadequacy. It is equally a fact of the environment and a fact of behavior. It is both physical and psychical, yet neither. An affordance points both ways, to the environment and to the observer" (Gibson 1979). Consequently Chemero comes to the conclusion that affordances are not properties of the environment. They are relations between particular aspects of animals and particular aspects of situations. Properties of the environment are not affordances in the absence of complementary properties of animals. Affordances belong to animal-environment system (Chemero, 2009). Affordances are possibilities for action that yield opportunities for engagement and participation. Affordance refers to what is available to the person to do something with (Van Lier, 2004). A text doesn't contain affordances by itself or affordances are not the properties of the text, they occur in the relation between the text and the observer (a person who perceives it).

What we perceive is not the text itself but the relation between us and the text. According to radical empiricist, perception is direct because it is an act that includes the thing perceived."Perceivables are relations between perceivers and aspects of situations" (Chemero, 2009). Thus reading a text I perceive the relation between me and the text and another person perceives the relation between him or her and the same text so that perceptions can remain private (thus it solves the problem of two minds). The main issue here is what we perceive is not in the environment alone, 
it is in the relation between an observer and the environment. These relations are open and dynamic, that is why text interpretation can be different every time it is perceived.

While interpreting the text field a person constructs his or her own language behavior together with others (text interpretation). Text field of the language (written language) is viewed as a domain of language interactions that is ontologically secondary with respect to natural language (speech) (Kravchenko, 2008). On this view, a written text (as an artifact) isn't separable from a human being because it's generated only in the process of interaction that shapes a consensual domain.

Speech and writing belong to different domains. On this view, a written text as an artifact isn't separable from a human being because it's generated only in the process of interaction that shapes a consensual domain. Writing helps overcome spatial and temporal limitations of languaging. The cognitive potential of conversing is extended with the invention of graphic sign. It becomes distributed in time.

Arkhipov believes that words and texts in the books on the shelves are objects that, in themselves, are meaningless. They become meaningful only when a human consciousness interacts with them (Arkhipov, 2001). They become linguistic signs only when thought and used by living human beings.

However, it should be noted that we suppose that texts allow to generate some potential meaning, affordances. A text as writing/reading environment does not contain meanings nor has properties by itself, it allows affordances which come to life in the interaction of a reader with the text, in the relation between the perceiver and the environment. In brief while reading we consider that texts allow affordances, meaning potentials we've got to generate but not an input-output structure.

\section{Reading as an active complex interactive phenomenon}

"What do we read? The message is not something given in advance - or given at all - but something created by interaction between writers and readers as participants in a particular communicative situation" (Harris, 2000).

Reading is a complex psychological process, connected with speech and different kinds of perception (acoustic, visual, spatial, etc.). This implies an action from the part of the reader, a person gets informed and experienced; reading stimulates the development of intelligence, influences behavior, changes and improves a person. The process of reading integrates perception, attention, memory, and thinking. Obviously, reading is hyper active phenomenon and cannot be considered as a passive one that involves reading words in a linear fashion and internalizing their meanings.

Opposing to the traditional point of view in linguistics that texts contain meaning and information, we consider that there is no perception of the meaning of the text physically, only metaphorically because the sense or the meaning is not inside the text, nor a content of it, that can be retrieved. On the opposite it is made or created every time anew it is perceived. The meaning is not "computable" from the linguistic (lexical, grammatical, and syntax) information alone. Sense-making allows people to perform creativity in a non-mechanical, standard way. Instead of perception of the meaning of the text, we will speak about sense making that is regarded as a unified interactive processes of perception and understanding (an active generating of ideas) which are closely correlated and do not exist separately without each other. For sense making, we need the body of the text which affords us to make predictions, anticipation, and draw conclusions, thus creating a projection of the text.

The term "projection of the text" was introduced by Zalevskaya. It is a mental thing, concept of the text, the essence of the text as a whole - a product of sense making of the text by the recipient that is to greater or lesser degree close to the author's projection of the text. She suggests a fivefold process: author - author's projection of the text - body of the text - recipient - recipient's projection of the text 
(Zalevskaya, 2005). From this perspective the only permanent thing from the five enumerated elements is the body of the text. The body of the text guides and constrains sense-making; however, saying this, we understand that it's the recipient who changes his or her inner state of thinking and emotions with the interaction of this part of the niche of the current environment.

Perception is not a passive encoding of data. If we take visual perception as an example, we may consider that light rays bounce off of an object and enter one's eyes. Those light rays then create a "sight" message that travels to the person's brain where the object is recorded. But that explanation is incomplete. The brain also acts on the message received from the eyes in ways that are not totally understood by scientists. The important point is that the real world is not necessarily the world that one perceives.

According to Gibson perception is an active exploration pick up and discrimination of information on the basis of the organism's interactions with the affordances of that organism's environment. Thus projection of the text is observer's perception and understanding of the body of the text that is not necessarily the original text.

Speaking about sign interpretation we would like to refer to Pierce's notion "infinity of interpretation" and "infinity of semiosis" (Peirce, 1958). It means that a text can be understood differently depending on who is reading it, in what circumstances, what place or environment and time. J. Derrida mentions about sign dynamism and he denies any rigid correlation between signifier and signified saying that semiosis is passé-partout. He invites readers to play a game of active interpretation, opening a great range of meanings (Derrida, 1972). Roland Barthes argues against the only meaning of the text and its final interpretation. He considers text as a kind of pleasure and reading as a walk or even sexual satisfaction (Barthes, 1994). The same goes with Umberto Eco who says that a text is a complex bunch of shapeless opportunities that stimulate a reader's interpretative drift. The reader as an active beginning of interpretation is the part of text creation (Eco, 1979). Thus, a human being interacting with the text as part of the environment creates a consensual domain of interactions. As a result he or she generates the meaning and value of the text on the basis of affordances created by the author. Reading isn't an individual process that is wholly dependent neither on the reader, nor on the text but it's distributed among the participants in the reading environment.

Reading is very similar to hypnosis to be yield to. We are imagining things, creating the image of what we've read, and we are doing things, constructing the imagery world. While reading, a person plunges into the reading environment that can be absorbing and a reader starts to live and act in that created world. Obviously, for better understanding of the author's intentions the reader should be carried way, totally involved in what he or she is reading. A general reading environment should be relaxing, free from everyday problem solving, distracted from mundane things to let thoughts flow freely like dreaming, creating bright, colorful, expressive images, in the "realm of the text" to be able to feel aesthetic pleasure or satisfaction from reading a good book.

Reading is a psycholinguistic guessing game (Goodman, 1967). The ability to anticipate and to produce guesses is vital in reading, just as the ability to anticipate what has not yet been heard is vital in listening.

\section{Conclusion}

A linguistic sign consists of a material form in terms of inscriptions that allows affordances for interpretation which occur in the interaction of the reader and the perceived text. The other part of a linguistic sign is a mnemonic structure comprising sign image of the material form and a concept. A linguistic sign comes to 
life in the human consciousness as the unity of a form and content. Perceiving an inscription (an external stimulus) the mnemonic structure is triggered in human mind. It comprises acoustic/graphic image of a sign form and a concept, some cognitive informational state of consciousness reflecting common, social and personal experience of an individual. The nature of a linguistic sign is revealed in the dynamic process of semiosis, and the signified as well as the signifier appear to be unified but discrete entities. A linguistic sign exists in the human consciousness as the unity of a form and content.

Reading as well as perception is an active process that demands energy for interpretation. A reader is not a passive receiver of information but a creator of a text. It is a complex psychological and cognitive process. We would like to finish with the following words by John Steinbeck:

To finish is a sadness to a writer-a little death.

He puts the last word down and it is done.

But it isn't really done. The story goes on and leaves the writer behind, for no story is ever done

(Steinbeck, 1975).

John Steinbeck's metaphorical phrase allows us to speculate further on the sense making, the role of the writer, reader and the text itself, three of which are obviously distributed in the time scale and distance and interact in the complex process of semiosis.

\section{Bibliographic references}

ARHIPOV, I.K. 2001. Chelovecheskij faktor v jazyke. SPb.: Nevskij in-t jaz. i kul'tury. 110 p. ISBN 5-89514-629-5

Barthes, R. 1994. The Semiotic Challenge. USA: University of California Press Berkeley. 293 p. ISBN 0520087844

CHEMERO, A. 2009. Radical Embodied Cognitive Science. Cambridge, Massachusetts: The MIT Press. 252 p. ISBN 978-0-262-51647-1

COWLEY, S.J. 2011. Distributed Language. Ed. by Cowley. Amsterdam / Philadelphia: John Benjamins Publishing Company. 211 p. ISBN 9789027202536

DAMASIO, A. 1995. Descartes' error: Emotion, reason and the human brain. New York: Avon Books, 1995. ISBN 0-399-13894-3

DERRIDA, J. 1972. Structure, sign, and play in the discourse of the human sciences. The structuralist controversy. The lang. of criticism of the sciences of man / ed. By Macksey R., Donato E. Baltimore, MD: Johns Hopkins University Press. pp. $253-$ 271. ISBN 9780415366427

ECO, U. 1979. The Role of the Reader Explorations in the Semiotics of Texts. Bloomington \& London: Indiana University Press. ISBN 10: 025320318X ISBN 13: 9780253203182

FORTUNATOV, F.F. 1956. Izbrannye trudy v 2-h t. M.: Uchpedgiz. V. 1. - 128 p.

FREGE, G. 1977. Smysl i denotat (Sense and denotat). Semiotika i informatika. M.: VINITI, 1977. - Issue 8. pp. 351 - 379. ISBN 9785397029827

GIBSON, J.J. 1977. The Theory of Affordances. In: Shaw, Robert/Bransford, John (Eds.). Perceiving, Acting and Knowing: Toward an ecological psychology. Hillsdale, NJ. Lawrence Erlbaum Associates. pp. 67 - 82. ISBN 0-89859-958-X

GIBSON, J.J. 1979. The Ecological Approach to Visual Perception. Boston: Houghton-Miffin, 315 p. ISBN-13: 978-1848725782. ISBN-10: 1848725787

GOODMAN, K. 1967. Reading: A psychological guessing game. Journal of the Reading Specialist, 6(4), pp. 126-135. DOI: 10.1080/19388076709556977

HALLIDAY, M.A.K. 2000. "Grammar and daily life: concurrence and complementarity". David G. Lookwood, Peter Fries and James Copeland (eds.) Functional Approaches to Language, Culture and Cognition: Papers in Honour of 
Sydney Lamb. (CILT163). Amsterdam/ Philadelphia: John Benjamins. pp. 221-237. ISBN 9789027299680

HARRIS, R. 1981. The Language Myth. London: Duckworth. 212 p. ISBN: 0715616595

HARRIS, R 2000. Rethinking writing. London: Athlone. 254 p. ISBN: 0826457983

KRAVCHENKO, A.V. 2001. Znak, znachenije, znanije: Ocherk kognitivnoi filosofii jazyka. Irkutsk: Irkutskaya oblastnaya tipografia. 261 p. ISBN 5-7971-0100-9

KRAVCHENKO, A.V. 2003. Sign, Meaning, Knowledge: An essay in the cognitive philosophy of language. Frankfurt/Main etc.: Peter Lang. 252 p. ISBN-13: 9780820460550. ISBN-10: 0820460559

KRAVCHENKO A.V. 2007. Essential properties of language, or, why language is not a code. In: Language Sciences, 29 (5). pp. 650-671. ISSN: 0388-0001

KRAVCHENKO, A.V. 2008. Biology of Cognition and Linguistic analysis. Franfurt an Main, Bern, Bruxelles, New York, Oxford, Wien. - Peter Lang. Internationaler Verlag der Wissenschaften. 304 p. ISBN 978-3-631-56647-3

KUBRJAKOVA, E.S. 1993. Vozvrashhajas' k opredeleniju znaka. Voprosy jazykoznanija № 4. pp. 20 - 27. ISSN 0373-658X

LOVE, N. 1998. The fixed-code theory. In: Roy Harris and George Wolfe (eds.), Integrational Linguistics: A first reader. Pergamon. pp. 49-67. ISBN-10: 0080433669. ISBN-13: 978-0080433660

LOVE, N. 2004. Cognition and the language myth. Language Sciences 26 (6). P. 525544. ISSN: 0388-0001

MAMARDASHVILI, M. 1989. "Kantian variatiants": Erika Kanta i sovremennost, Riga. 320 p.

MATURANA, H. 1970. Biology of cognition. BCL Research Report 9.0, Urbana, IL: University of Illinois. 58 p. ISBN 978-9027710161

MATURANA, H. 1978. Biology of language: The epistemology of reality. In G. Miller \& E. Lenneberg (Eds.), Psychology and biology of language and thought. New York: Academic Press. pp. 27-63. ISBN 0-12-497750-2

MATURANA, H. \& VARELA, F. 1987. The tree of knowledge: The biological roots of human understanding. Boston: Shambhala. 269 p. ISBN 0-87773-642-1

MORRIS, C. W. 1938. Foundations of the theory of signs. International Encyclopedia of United states. Chicago, Vol. 1, part 2. pp. 312-320. ISBN 0226575772

OGDEN, C.K. 1923. The meaning of «meaning». London. - 363 p. ISBN 0-15658446-8

PESINA, S.A. 2005. Polisemija v kognitivnom aspekte. SPb. : RGPU im. A. I. Gercena. 325 p. ISBN 5-89514-629-5

PIERCE, C.S. 1958. Collected papers of Charles Sanders Pierce (ed. By C. Hartshorne \& P. Weiss). - Cambridge: Harvard University Press. Vol. 2. Elements of Logic. ISBN: 978-1-57085-185-8

POTEBNJA, A A. 1993. Mysl' i jazyk (Thought and language). - Kiev: Sitno. 192 p. ISBN 5-87604-053-3

STEINBECK, J. 1975. QUOTES JOHN STEINBECK, The Paris Review. (Online) Available at: http://www.notablequotes.com/s/steinbeck_john.html\#XRbuJiqc6TJcs3Rx.99. (November 12, 2015).

VAN LIER, L. 2004. The ecology and semiotics of language learning: A sociocultural perspective. Monterey Institute of International Studies, Norwell, MA, USA. - 252 p. ISBN-13: 978-1402079931 ISBN-10: 1402079931

VOLOSHINOV, V. 1973. Marxism and the Philosophy of Language, Harvard University Press. ISBN 9780674550988

ZALEVSKAJA, A.A. 2001. Tekst i ego ponimanie. Voprosy jazykoznanija. № 4. pp. $62-73$. ISSN 0373-658X

10 
ZALEVSKAJA, A.A. 2005. Slovo. Tekst. Moscow: Gnozis, 2005. 543 p. ISBN 57333-0145-7

Words: 4996

Characters: $32173(17,89$ standard pages)

Assoc. Prof. Olga Karamalak, Ph.D.

School of Foreign Languages

National Research University Higher School of Economics

12/4 Pionerskaya ul.

115054 Moscow

Russia

olgakaramalak@yandex.ru

Prof. Svetlana Pesina, Dr. of Philology and Philosophy

English Language Department

Nosov Magnitogorsk State Technical University

38 Lenin Street

455000 Magnitogorsk

Russia

spesina@bk.ru

11

XLinguae Journal, Volume 10 Issue 1, January 2017, ISSN 1337-8384 